\title{
The family's role as a support network for people living with HIV/AIDS: a review of Brazilian research into the theme
}

Leonara Maria Souza da Silva ${ }^{1}$

Jeane Saskya Campos Tavares ${ }^{1}$

${ }^{1}$ Centro de Ciências da Saúde, Universidade Federal do Recôncavo da Bahia. Av. Carlos Amaral 1015, Cajueiro. 44570-000 Santo Antônio de Jesus Bahia Brasil. leonaramsds@gmail.com

\begin{abstract}
The study of HIV transmission and the implementation of AIDS prevention actions recognize the importance of social networks in the transmission of the disease, the adherence to treatment and the quality of life of those infected. For this relevance there was a review of articles on social support networks to people living with HIV /AIDS available in the Virtual Health Library (VHL) were published in Brazil between 2002 and 2012. In this study 31 articles were used from journals covering the following áreas: Nursing ( $n$ = 15), Psychology $(n=6)$ and Science Health / Biomedica $(n=6)$, were included, which some principal authors were affiliated to higher education public institutions $(n=17)$. In relation to the methodology used, priority wasgiven to conducting: qualitative research $(n=18)$, cross-sectional studies $(n=19)$ and studies that involved talking to people living with HIV/AIDS $(n=13)$. Particular importance was placed on analytic categories related to: adherence to treatment $(n=6)$, the family $(n=4)$, vulnerability $(n=3)$ and support from social networks $(n=5)$. Within this paper we argue for more investments into studies that focus on the family, carers and their households, as well as deepening the theoretical study of the themes discussed and the use of developed theories for the analysis of Social Networks.
\end{abstract}

Keywords HIV/AIDS, Social networks, Social support, Family, Adherence and Home care 


\section{Introduction}

Theories around social networks started to be developed in the 1930s in the area of Social Sciences in order to better understand social systems at both micro and macro-sociological levels. In the second half of the 20th Century, the use of these theories was not just limited to Sociology and Anthropology. They have been extended to other areas such as education, administration and health.

In the latter, a memorable use of studies into social networks and the development of analysis in this area occurred during the HIV epidemic (Human Immunodeficiency Virus), in the 1980s. Taking into account the unique nature of this type of infection, the study into the transmission of the disease in social networks proved to be one of the main strategies for: the location mapping of patients, early detection and prevention of HIV and AIDS (Acquired Immunodeficiency Syndrome). With this approach, starting from the year 2000, the study of social networks continues to be an important strategy for understanding epidemiological and psychosocial issues related to this epidemic ${ }^{1}$.

In Brazil, focus has been placed on social networks in discussions about STDs (Sexually Transmitted Diseases), as can be seen in the National Policy on STD/AIDS 2 . This document proposes two models of intervention to promote health and prevent STD/AIDS, in which social networks are designated as fundamental. The first relates to models for behavioral changes of the individual. The other relates to models for intervention into the changing of group behavior (the collective) which considers the importance of the establishment of ties and social interactions:

[...] The perception of risk of HIV and for the misuse of drugs is directly related to the ties and communicational links established which involves a continuous process of interaction. With this in mind, it is essential to: analyze the composition of social networks within communities, the activities of these networks and whether they adhere to safe practices and the inherent risks that exist in some networks (the identification of social networks with high risks and 'bridge populations').

One of the aims of the prevention strategy is that proposed actions should strengthen social networks, in order to: promote health, prevent the transmission of the disease, the provision of social support, and develop alternatives coping mechanisms. The section in the strategy on diagnosis and assistance, which provides for the
Prevention and Control of STD/HIV/AIDS in the Primary Health Network, ought to, in Bra$\mathrm{zil}^{2}$ "produce informative and educational material about STD/HIV and AIDs, for families that it aims to reach". This places due recognition of the importance of the family and social networks which are essential for the development of individuals in a given culture. They are also extremely important in the context of public policies and in the health sector and in covering benefits and services $^{3}$.

This is because it is in the family that one can see care and attention which is essential in the context of Health. This was noted by Gutierrez and Minayo ${ }^{4}$ :

[...] Interactions are considered affective and necessary for healthy mental development and for the maturing of one's personality. Also in the family one learns about the importance of hygiene, eating habits and the need to stick to the instructions given for medical treatments... All of the aforementioned can be seen through the daily actions taken by the family which allows for: the identification of diseases, the search for medical intervention at the appropriate time, encouraging self-help and last but not least, recognition of the importance of emotional support.

The family network has a decisive influence on the health care provided to someone who is infected by HIV/AIDS, particularly for adherence to antiretroviral therapy (ART), which requires changes in routines and habits of all those involved. The expectation is that families have positive affects according to Botti et al..$^{5}$ :

[...] The family positively influences self-esteem, self-confidence and the self-image of the infected person. It also brings benefits in relation to the treatment given and it gives moral support to the infected person showing them that life is worth living. The family makes it known that being HIV positive isn't a reason to take early retirement, to stopp studying or to stop pursuing other social activities.

Nonetheless, little recognition is given to the role of the family in the National Program. We were only able to find one document from the Ministry of Health for families that live with HIV/ AIDS, a book entitled Learning about HIV/AIDS and Sexually Transmitted Diseases ${ }^{6}$. With accessible language and illustrations, the book provides guidance on how to prevent and detect sexually transmitted diseases and HIV/AIDS. It also provides guidance on how social networks can help with the care of those who fall ill, through the provision of social support. 
However, a decade has passed since its publication, and since then other publications have not been released that are directed to the family on the website of the Ministry of Health at the time of publishing this article. Even in the recent publication entitled Brazilian Policy on AIDS: Results, Advances and Perspectives ${ }^{7}$ there is no data regarding families. There appears to be no recognition given to the impact of the diagnosis and treatment of HIV/AIDS on all those involved, and as the publication indicates the non-prioritization of actions that support families living with HIV/AIDS.

In relation to scientific studies on the family in this context, we agreed with Gutierrez and Minayo ${ }^{4}$, in that the current available studies do not describe definitively how families provide care and what criteria they use to care for the health of its members. What caught our attention was the lack of studies published focusing on the family as a social support network. This is in spite of the fact that the Brazilian Health System has been shaped and defined as a health network that encompasses family and community networks.

Therefore, the objective of this article is to present the main results of a review of articles published in Brazil between 2002 and 2012, which focused on the family as a support network for people living with HIV/AIDS. Specifically, we sought to categorize these articles, analyze the similarities between objectives, and to look at the theoretical and methodological strategies adopted and their results.

\section{Methodology}

In our bibliographic research, we searched for scientific articles produced in Brazil that were published in the Virtual Health Library (VHL), between 2002 and 2012. We considered only the articles included in the category "General Health Sciences" (Lilacs - Latin American and Caribbean Health Sciences, Cochrane Library and SciELO Scientific Electronic Library Onlin). We used the following descriptors, in accordance with the basis of Health Sciences Descriptors (DeCS) for our searches: HIV, AIDS, social networks, social support, family, adherence and home care.

After locating and selecting the articles, the information was collated according to the following analytic categories: identification of article (periodical, year of publication, title of the article), authorship (number of authors, their educational background, the institutions that they belong to), nature of the text and theoretical frameworks adopted, objectives (including method, design, participants, local strategies and tools used in the studies) and results (covering consistency, objectives/theory/methodology/results).

We found 39 articles, of which 31 were analyzed where we were able to obtain full access to the complete text. We put into tables the information from the selected articles and conducted statistical analysis covering frequency and average using the statistical program (SPSS17) Statistical Package for the Social Sciences.

\section{Results and discussion}

\section{Categorization of articles}

There was a higher concentration of publications in journals in the areas of Nursing $(n=15)$, Psychology $(n=6)$ and Health Sciences/Biomedicine $(n=6)$ (Table 1$)$. As to the year of publication, there was an average of 3 publications per year, with a greater concentration in the period from 2011, when 5 articles were published.

The majority of the studies analyzed $(n=$ 17) were produced by first time authors from the field of Nursing $(\mathrm{n}=10)$ and in this category there was only one publication covering our topic. In part, we understood this to be an article that was published in response to the requirements of funding agencies and due to a "productivist" vision in postgraduate programs, which fosters the quantitative increase of publications ${ }^{8,9}$.

The public Higher Education Institutions (HEIs) are the main institutions where the first time authors came from $(n=17)$, among these institutions were: the Federal Universities ( $\mathrm{n}=$ 12), the University of Brasilia $(n=3)$ and the Federal University of Rio Grande do Sul ( $\mathrm{n}=$ 3). Other institutions included: health care institutions, such as the Specialized Care Services in HIV/AIDS Clinic and Municipal Health Care Centers covering STD/HIV/AIDS $(\mathrm{n}=5)$. It is essential to mention the dual importance of the production of scientific research in this area which involves representatives of health services, because they have access to the daily lives of families. The first important fact is that it contributes to better quality studies and secondly health care representatives benefit from the scientific rigor being used in their area.

As regards the nature of the texts, we identified research reports designed as: being investigative $(n=26)$; using scientific trials $(n=3)$, being 


\begin{tabular}{|c|c|}
\hline Area & Artiles published by journal \\
\hline Nursing & $\begin{array}{l}\text { The Brazilian Journal on Nursing }{ }^{10-12} \\
\text { The University of São Paulo School of Nursing Journal }{ }^{13-15} \\
\text { The Nursing Journal UERJ } J^{5,16,17} \\
\text { The Latin American Journal on Nursing }{ }^{18} \\
\text { Nursing Acta Paulista }{ }^{19} \\
\text { The Anna Nery School of Nursing }^{20-22} \\
\text { Nursing Text and Context }{ }^{23}\end{array}$ \\
\hline Psychology & $\begin{array}{l}\text { Psychology: Theory and Research Psicologia }{ }^{24-27} \\
\text { Psychology: Reflections and Critical Thinking } \\
\text { Psychology in Focus }{ }^{29}\end{array}$ \\
\hline Public Health/ Collective Health & $\begin{array}{l}\text { Science and Collective Health }{ }^{30} \\
\text { The Book on Public Health }\end{array}$ \\
\hline Health Science/Biomedicine & $\begin{array}{l}\text { Interface - Communication, Health and Education }{ }^{34} \\
\text { The Files on Health Science }{ }^{35} \\
\text { The Psychiatry Journal }{ }^{36} \\
\text { The Brazilian Journal on Tropical Medicine } e^{37} \\
\text { The Pan American Journal on Infectology }{ }^{38} \\
\text { Acta Scientiarum. Health Science }\end{array}$ \\
\hline
\end{tabular}

used for the development of theories $(n=1)$, being used for used for the analysis of theoretical/ methodological positions $(n=2)$, being involved in literature review $(n=1)$ and having participant's accounts $(n=1)$. We noted that there was not a great amount of studies in this area particularly in relation to registering the experience of family members living with HIV/AIDS. This may be due to the fact that the majority of the articles, have been developed by professionals doing post-graduate courses that put an emphasis on other research. Also of the 19 publications that were found only 8 were accepted into our study.

In some research reports, people living with HIV/AIDS were the only participants in almost half of the articles $(n=13)$. In a few studies there were only family members or carers $(n=8)$ and there were even fewer amounts of studies that had participants who were family members/carers and those with HIV $(n=6)$. There was a large variation in the number of participants in these studies ranging from between 03 and 13 participants $(\mathrm{n}=11), 14$ and $24(\mathrm{n}=6)$ and more than $80(n=6)$.

With respect to the locations of the research, the greater part was performed in: outpatient clinics in public hospitals $(n=9)$, Specialized Centers/renowned Health Centers $(n=6)$ and in the residence of family members or carers $(\mathrm{n}=$ 2). In part, this limitation in relation to research being carried out in the locations with formal networks may be due to the many ethical issues involved in research of this nature amongst this demographic. Within this demographic when a diagnosis is made, few people are told either in the family or among friends ${ }^{37}$. Also neighbors are omitted completely from knowing anything. Apart from dealing with the issue of family members not knowing of the diagnosis, researchers came across potential problems of a diagnosis where there is a relationship (i.e. heterosexual and/or homosexual) and transmission has occurred through an extramarital affair or drug abuse.

In relation to the methodology, the most frequently used was the cross-sectional method (n $=19$ ). After which priority was given to qualitative research $(\mathrm{n}=18)$ followed by a mixture of quantitative/qualitative research $(n=6)$ and finally just quantitative research $(n=3)$. The use of interviews was the favored method for obtaining data $(n=23)$, with emphasis being placed on the use of semi-structured interviews $(n=6)$. Information taken from interviews was augmented by information from: analysis of documents and records $(n=5)$, the use of focus groups $(n=1)$ and 
the use of evaluations $(n=1)$. In the majority of our studies we focused on analyzing content $(\mathrm{n}=$ 17). We also put emphasis on analyzing percentage statistics and averages $(n=5)$.

Almost half of the articles $(n=15)$ had as an objective to describe and/or analyze processes or factors (covering vulnerability, resilience and protection) that carers, patients or family members have to deal with. Other articles sought to: evaluate what hinders or helps with the adherence to AIDS therapies $(n=6)$, investigate the relationship between concepts, meanings and ideas in the care and treatment of patients $(n=3)$, evaluate techniques and methods $(n=2)$ and to understand how those who are ill live with their illness and what they experience $(n=2)$.

We believe that there was consistency between: objectives, the theoretical frameworks, methodologies used and the end results in the majority of studies $(n=26)$. Identified inconsistencies can be attributed to: the inadequacy of places chosen to conduct interviews, criticism made by the authors themselves ${ }^{35}(\mathrm{n}=1)$, mischaracterization or lack of understanding in the design of studies ${ }^{21,33}(\mathrm{n}=2)^{36}(\mathrm{n}=1)$ and omission of results obtained through interviews ${ }^{38}$ (n $=1)$.

In relation to theoretical frameworks used in this area, no studies were found that covered the main study methods that should be used in the field of social networks. Also in relation to theories within this area, no explicit references were found that dealt with the main approaches for studying social networks in such fields as: Structuralism, Social Action or the Theory of donation $^{40}$. In general, the authors do not clarify their theoretical assumptions which means that they provided analysis in the following principal categories: adherence to treatment $(n=6)$, the family $(\mathrm{n}=4)$, vulnerability $(\mathrm{n}=3)$ and support/social network $(\mathrm{n}=5)$.

\section{Adherence to Treatment: definitions and intervening factors}

Advances in detection and treatment led to better quality of life and longevity for people infected with HIV, despite being a chronic health condition. However, despite the benefits, there are many that do not adhere to this therapy and this is one of the main topics covered by the studies that were analyzed.

Several authors ${ }^{10,11,17,29,32,37}$ who tackled the issues of adherence to treatments, sought to understand what helped and hindered sticking to prescribed treatments. They used the benchmark criterion for defining the rate of adherence of 95\%, meaning the patient would be accepted as having adhered to the treatment if he/she took at least $95 \%$ of the prescribed doses of ART ${ }^{10,29,32,37}$.

We noted the different terminology used to refer to the above process such as "adhesion" $10,11,29,37$ and "adherence" 32 . Although considered to be synonyms, (as noted in DeCS-Descriptors in health Science), the second is a physical characteristic that relates to objects that allow you to connect. In the analyzed articles, adhesion is understood in two ways: (a) the taking of the ART medication in accordance with what is prescribe by a doctor ${ }^{11,32,37}$ and (b) the result of what is agreed between the patient and the health professional ${ }^{10,17,29}$. This is consistent with the guidelines for strengthening actions on adherence to treatment for people living with HIV and AIDS ${ }^{41}$, which aims to allow the patient to be empowered, independent minded and have the ability to care for themselves.

\section{Complicating Factors and facilitators}

What was common were factors that made it difficult for the patient to adhere to the treatment such as: the nature of the medication and treatment, changes in the routine of the patients' lives, and changes in work activities.

In general, the side effects of the medication were the biggest impediments to adherence to treatment. However, in one study ${ }^{37}$ there was found to be no significant difference between adherents to the treatment and non-adherents. The conclusion was that "the adherent patients showed a greater repertoire of strategies to remember the medication and to circumvent the difficulties encountered, suggesting a more active role in your treatment".

Other factors which influenced non-adherence included: the amount of drugs required ${ }^{11,29}$, the rigidity of hours covering when to take the medication, having to wake up early, delays ingesting the medication and the loss of the medication doses ${ }^{10,29}$,All of these can be obstacles in the therapy. Other impediments were the use of tablets when fasting, with food or combined with other tablets, which required the patient to be organized and committed ${ }^{17}$. This impediment was similar to the one of having to take medication on a daily basis without any end in sight ${ }^{17,29}$.

Other factors that determine adherence included: changes in routines, losses incurred through changes in working activities ${ }^{10,17}$, possi- 
ble unemployment $\mathrm{t}^{32}$ and the fear of discrimination $^{11}$ in the work place.

Factors that helped with adherence included: medication with little side effects and the support provided by social networks. In relation to the absence of side effects, those who did not have nausea, headaches, and other symptoms and signs, were more committed to following the therapy ${ }^{10,11}$. A good relationship with the social network is important for the good adherence $10,11,17,37$, because according to Silvio Padoin et al. ${ }^{17}$ "secondary social networks, evidenced in the relationships established with family members, friends, neighbors and health professionals, helps in the adherence to treatment".

Other factors that facilitated adherence to treatment that were analyzed in specific studies included: the sensation of well-being that the therapy can provide ${ }^{10}$, having fixed employment, early diagnosis of the infection ${ }^{32}$, the beneficial effects of the medications for health ${ }^{29}$, living conditions $^{37}$, attention given to any children involved, raising awareness about the severity of the disease and having an understanding of the importance of the treatment ${ }^{11}$.

\section{Impact of illness on the family}

We noted that there were hardly any theoretical studies on the family in this area. The studies that do exist do not touch on the historical changes or the make-up of the family over the last few centuries. Only one study ${ }^{18}$ purported to give a definition of the family as "a group formed by people who are united by affective bonds, through blood relations or not, inserted in a social and time bound context ". In this study ${ }^{18}$, "the relative or carer is the person on whom the patient depends ". Others gave no definition, but emphasized the importance of the family ${ }^{5,16,39}$ in AIDS. According to Sousa et al. ${ }^{39}$, the family is:

[...] A source of support for the individual with AIDS, contributing to their physical and mental wellbeing. However, the meanings that cultures attach to the disease may affect the behavior of the family, with respect to the individual with AIDS, leading to discrimination or complete removal from the family circle.

In this sense, it is considered that to focus on the ill individual fails to take into account the role of the entire family. Sousa et al add the following ${ }^{39}$, "not taking into account the care given by families is to forget the role of the family as well as its history, and its ability to deal with situations like diseases". In general, the mother, the wife and the child feel a sense of responsibility for providing care, with emphasis being placed on mothers as first hand carers ${ }^{5,18}$. This corresponds to the historic role of female carers in the family in our society.

The repercussions for the family and the patient are such that a process of adaption occurs and changes also occur in relationships within the family and society ${ }^{18}$. Denial and the expression of other strong emotions are the mechanisms used by the patient and families to deal with real life or hypothetical situations ${ }^{18,39}$.

Families normally do not discuss this disease outside of themselves out of fear of social stigmatization or discrimination ${ }^{5,18,39}$. Because of this, the carers feel isolated and alone as they do not receive support from neighbors and friends and are therefore required to take on the full burden alone. Throughout the course of the illness there is: emotional instability, the feeling of loss or suffering in a life that will be cut short, complex treatment, the need to deal with the onset of symptoms and dealing with the aggressiveness of the patient ${ }^{18}$.

Family members often encounter limitations or difficulties in providing care and living with someone who is ill. Therefore health care professionals should care for both the person with HIV and their families ${ }^{5,18}$.

\section{Determinants of vulnerability in the context of HIV/AIDS}

The articles that analyzed the category of "Vulnerability", in general, covered determinants, and relationships within the family. We looked at the work of Schaurich and De Freitas ${ }^{14}$, which highlights the role of the family in the context of HIV/AIDS and defines "vulnerability" as "the chance of being exposed to an illness and in becoming ill as a result of a number of aspects not only individual, but also collective and contextual, which entails greater susceptibility" ${ }^{\prime 1}$. This was the only study that gave a definition.

It is understood that this category provides comprehensive understanding of the HIV/AIDS epidemic, because as noted by Marques et al..$^{33}$, "taking on a deterministic reasoning of an individual in relation to the collective-social, and vice-versa, when an analysis of vulnerability is undertaken this allows for an objective look at the different disciplines and technical areas involved in health". However, the term vulnerability presents difficulties and limitations, according to Schaurich and Freitas ${ }^{14}$ : 
[...] 1) its use in the context of the AIDS epidemic is recent and there is a need for more studies and research to better understand their benefits and their limitations; 2) being an all embracive concept that is complex with no directional focus, it may seem more theoretical than practical and this makes the choice difficult and makes knowing what actions and policies to pursue difficult as well 3) vulnerability is: multidimensional, comes in different degrees and is dynamic.

In relation to interdependent plans of determination ${ }^{16}$ which can be categorized as individual, social and programmatic, we observed discussions about these, in three publications ${ }^{14,16,33}$. To define them, Schaurich and de Freitas ${ }^{14}$ tell us that the first one refers to behaviors and cognitions that can allow the infection and/or illness to progress. The second relates to access to information through institutions (health and education) and puts emphasis on the persons conditions at leisure. The pragmatic plan refers to the State's commitment to fighting the AIDS epidemic through: prevention, education, investment/financial assistance, investment in human and physical resources, investment in the quality of management, the monitoring of health programs and being committed to taking any necessary actions ${ }^{14}$.

At the individual level, which is only dealt with by Cardoso et al. ${ }^{16}$, the people who live with HIV/AIDS, had knowledge of the forms of transmission of the virus and after overcoming the symptomatic phase, "they, typically, valued the adoption of healthier living habits".

At the social level, the absence of seeking preventive care has a correlation with the insensitivity of health professionals regarding the current epidemiological profile of HIV/AIDS ${ }^{16}$. Also in relation to access to health care institutions and the care they provided, we identified ${ }^{33}$ differences in the communication of diagnosis amongst different people. Where adolescents were infected by vertical transmission, communication was "done with care and attention being paid in relation to its impact on the lives of these young people". This was not the case for other groups who were infected through sexual intercourse or who were unaware of the mode of transmission of HIV. Different strategies were used to give diagnosis.

According to Cardoso et al. ${ }^{16}$ in relation to the pragmatic plan, only one person who had been part of the study became aware of their HIV status through a routine exam. This shows the lack of preventative initiatives that were in existence. What was also shown was the importance of understanding the way in which the services and health programs can promote the reduction of vulnerability in adolescents living with HIV/ AIDS, increasing their psychosocial well-being and full enjoyment of their human rights ${ }^{33}$.

We observed through studies in this category a discussion concerning diagnosis and vulnerability ${ }^{16,33}$. Therefore upon discovering that one was HIV positive, Cardoso et al. ${ }^{16}$ noted changes which involved a mixture of emotions ranging from negativity to feeling better due to knowing. This occurred particularly when "they were informed about the possibilities of treatment and prognosis of the disease, only then did the negative feelings decrease". The following factors influenced sufferers disclosing their disease to others: the fear of prejudice and discrimination, reaction of a child, negative consequences that may come after the disclosure, the discomfort involved in telling the family and fear due to the sheer weight of responsibility that comes with disclosures. The carers also highlighted the difficulties of a disclosures which exposes the private life of the family as the individual may have been involved in the use of drugs, homosexuality or other acts. On the other hand, once a revelation is made, there was a feeling of relief on the part of those that were interviewed ${ }^{33}$.

After the revelation, comes the need to cope with emotions and the idea that life goes on. This attitude brings with it positive changes, which includes placing more value on life ${ }^{16}$.

\section{Social Support and HIV/AIDS}

In the same way that the category "family" was used, the studies used the terms "social support", and "support network", without presenting concepts or theoretical considerations. The terms "formal and informal social support systems", "networks" and "social support" were defined in one study ${ }^{21}$ as:

[...] A hierarchical system with people in groups that maintain links between themselves involving both giving and receiving. It remains in existence throughout the people's lives and it meets the basic needs of mankind. However, its structure and functions can change, depending on the needs of people.

Among the articles analyzed, one study ${ }^{25}$ investigated the factorial structure and psychometric properties of the Scale of Social Support for People Living with HIV/AIDS. This study presented arguments more consistent about this theme. There were differences in the studies where some emphasized structural aspects and others functional. Through the same studies two functional 
categories were discovered, namely instrumental and operational ${ }^{25}$. They covered: giving help to resolve day to day situations, providing material and financial support which can aid in the management and resolution of situations/problems in daily life. This was seen particularly in the provision of financial and emotional support and raising self-esteem. It also involves "behaviors such as listening, provide your attention to someone or making a person feel loved and care for". They ${ }^{25}$ also touch on theoretical models on social support (Buffer and Main Effects) and how they have been studied in the context of HIV/AIDS.

All of the studies emphasized that social support networks help people to deal with HIV, since "they reduce the negative consequences of stressful events related to the infection"12. They highlighted that members of these networks stated that they were satisfied with the support received from their networks ${ }^{12,24-26}$. In this sense, Galvão and Paiva noted that ${ }^{12}$ :

[...] As regards the social support networks for HIV positive suffers, it is important for the person not to feel alone in coping with a disease with the peculiarities of HIV, which can be marked by: prejudice, abandonment and the feeling that life is finite. We observed that with the support of family and friends the HIV sufferer is able to live with the infection with more courage to continue living despite having a chronic disease that requires constant care and attention.

The establishment of a relationship of trust, without judgment on the part of health professionals, in addition to the social support and help come from the family, has strengthened infected women allowing them to receive help to be treated. This means having someone they can trust, for example, to take care of her children ${ }^{12}$, or having someone that allows them to dedicate themselves to their babies ${ }^{26}$. Support is also sought through religion or other spiritual avenues ${ }^{12,21,24}$.

Among the many forms of support offered by social networks, the following were highlighted: financial aid, child care, completion of household chores, and even support in relation to the diagnosis ${ }^{26}$. However, five out of the six mothers interviewed in this study ${ }^{26}$ reported having been dissatisfied with the negative reaction of their spouse when they were told: of a pregnancy or a disease. They also disliked the absence of them at the time of child birth/post-delivery, and complained about the lack of child care, lack of financial aid, and conjugal arguments.

However, useful support was offered by the following: the partner, spouse, companion or boyfriend, followed by family members, who lived (or not) with the patient, and then friends ${ }^{25,26}$. In relation to the provision of emotional support, this was common among health professionals, members of religious institutions and non-governmental organizations related to HIV/AIDS ${ }^{25}$.

In relation to the revealing of a diagnosis only close members of social networks were told due to fear of the consequences of a wider disclosure causing prejudice or discrimination ${ }^{12,24}$. It was common for all the mothers in one study ${ }^{26}$ to avoid knowing a diagnosis and to reduce their support networks (through voluntary or involuntary means) due to: living far from their families, marital disputes or health problems. Also in relation to the diagnosis and social relations, Seidl et al. ${ }^{24}$, notes that the majority $(\mathrm{n}=40)$ of carers said that infected children participated in activities through socializing with their family and with other children. However, he also noted that $(\mathrm{n}=15)$ restriction were placed on their activities to prevent the transmission of the disease.

Seidl et al. ${ }^{24}$ studied the disclosure of the disease which proved to be necessary in 11 cases, because of absences of the child or the administering of medication in classes. As for the knowledge of their condition on the part of the child/adolescent, 13 of them knew of the diagnosis; however, the majority $(\mathrm{n}=25)$ had no knowledge of the disease. The decision regarding the disclosure seems to be related to: the capacity of the child to understand these issues, the need for self-care and the care that needs to be taken for possible future sexual relations ${ }^{24}$.

We also noted changes in the lives of elderly people once diagnosed in that they showed signs of feeling inferior, having low self-esteem, social isolation, and even resulting in suicide attempts ${ }^{21}$. In relation to work activities, the respondents reported that prior to the infection, they felt able to work, but after it was difficult. However elderly people were able to get the most out of their lives (going to social clubs for the elderly, for example), due to being in retirement and not having any more employment obligations ${ }^{21}$.

Seidl et al. ${ }^{24}$ noted that the majority of children/adolescents $(n=25)$, according to their primary carers, did not present any difficulties in their psychomotor, cognitive, relational, emotional and social development. Apparently, there seems to be no correlation between low school performance and a diagnosis of AIDS, since only three carers stated that a particular child's performance was poor ${ }^{24}$. The majority of the carers (n =30) considered adherence to ART to be good, 
however 11 cases indicated problems or difficulties, such as: sticking to times for taking the medication, the taste of the medication, the presence of side effects and difficulty in accessing regular health service ${ }^{24}$.

From the analysis of these articles, we came to the understanding that social networks can both hinder and contribute to the quality of life of an HIV suffer. The diagnosis, the treatment and the stigma that surrounds this chronic condition directly influences the type and quality of support that is given.

\section{Final Considerations}

We ended by noting the absence of theoretical studies in this area and the lack of explanations of basic concepts in most of studies that we analyzed covering family support and social networks. This in itself can compromise the very understanding of any research conducted as well as its ability to aid in the provision of recommendations for the Brazilian Policy on AIDS ${ }^{7}$. Also better information on the methods of analysis are necessary when studies are done, particularly in studies that seek to use the theories concerning social networks. These studies should use appropriate methodology when studying networks.

There is little scientific research on the family in this area when one considers: the period

\section{Collaborations}

LMS Silva contributed in the development of this paper as a research student, principally in production of the research data that came from the articles and she wrote the greater part of its content. JSC Tavares drafted and coordinated the research and put forward the concepts and design of this paper. He also wrote part of the final submitted version.

\section{Acknowledgments}

We wish to acknowledge the support of the National Council for Scientific and Technological Development (CNPq) for scientific grant. investigated, the relevance of this epidemic, the participation of family members, the spread of HIV and the impact of the illness. We recognize the difficulty of gaining access to family members due to ethical issues, prejudice and fear of stigma. Nevertheless investment in studies is necessary and these studies should prioritize the family and carers as the basis of any research.

We believe that this change is particularly necessary, because studies in health institutions don't allow for observation to be made of: the daily lives of families, their dynamic operations and what generally takes place in homes all which may be influence the quality of the data produced through the use of qualitative research tools. This is particularly the case where we considered our main objectives.

It is also important that there be the dissemination of reports showing the treatment and care given to families by health professionals. This is because the knowledge and dissemination of care methods developed by health care professionals contributes to a broader understanding of family behaviors and for the development of adequate strategies of care for the population as a whole.

Finally, we emphasize the need for new studies that discuss and propose innovative actions directed to families, because they have the ability to care for a family member that falls ill and that doesn't have the support from other social support networks.

\section{References}

1. Barbosa MTS, Byington MRL, Struchiner CJ. Modelos dinâmicos e redes sociais: revisão e reflexões a respeito de sua contribuição para o entendimento da epidemia do HIV. Cad Saude Publica 2000; 16(Supl. 1):37-51.

2. Brasil. Ministério da Saúde (MS). Política Nacional de DST/AIDS: Princípios, diretrizes e estratégias. Brasília: MS; 1999 [acessado 2012 fev 7]. Disponível em: http:// bvsms.saude.gov.br/bvs/publicacoes/cd03_17.pdf

3. Serapioni M. O papel da família e das redes primárias na reestruturação das políticas sociais. Cien Saude Colet 2005; 10(Supl.):243-253.

4. Gutierrez DMD, Minayo MCS. Produção de conhecimento sobre cuidados da saúde no âmbito da família. Cien Saude Colet 2010; 15(Supl.):1497-1508.

5. Botti LM, Leite BG, Prado FM, Wadman PAM, Marcon, SS. Convivência e percepção do cuidado familiar ao portador de HIV/AIDS. Rev. enferm. UERJ 2009; 17 (3):400-405.

6. Brasil. Ministério da Saúde (MS). Aprendendo sobre AIDS e doenças sexualmente transmissíveis: livro da família. 3. a Ed. Brasília: MS; 2001. [acessado 2013 mar 13]. Disponível em: http://www.aids.gov.br/sites/default/files/Livro_da_Familia.pdf 
7. Brasil. Ministério da Saúde (MS). Política brasileira de enfrentamento da AIDS: Resultados, Avanços e Perspectivas. Brasília: MS; 2012. [acessado 2013 jul 12] Disponível em: http://www.aids.gov.pdf.

8. Meneghini R. Visibilidade internacional da produção brasileira em saúde coletiva. Cad Saude Publica 2010; 26(6):1058-1059.

9. Barros AJD. Produção científica em saúde coletiva: perfil dos periódicos e avaliação pela Capes. Rev Saude Publica 2006; 40(Esp.):43-49.

10. Santos WJ, Drumond EF, Gomes AS, Corrêa CM, Freitas MIF. Barreiras e aspectos facilitadores da adesão à terapia antirretroviral em Belo Horizonte-MG. Rev. bras. enferm. 2011; 64(6):1028-1037.

11. Silva ALCN, Waidman MAP, Marcon SS. Adesão e não -adesão à terapia anti-retroviral: as duas faces de uma mesma vivência. Rev. bras. enferm. 2009; 62(2):213-220.

12. Galvão MTG, Paiva SS. Vivências para o enfrentamento do HIV entre mulheres infectadas pelo vírus. Rev. bras. enferm. 2011; 64(6):1022-1027.

13. Silveira EAA, Carvalho AMP. Suporte relacionado ao cuidado em saúde ao doente com aids: o modelo de comboio e a enfermagem. Rev. esc. enferm. USP 2011; 45(3):645-650.

14. Schaurich D, Freitas HMB. O referencial de vulnerabilidade ao HIV/AIDS aplicado às famílias: um exercício reflexivo. Rev. esc. enferm. USP 2011; 45(4):989-995.

15. Schaurich D. Revelação do diagnóstico de aids à criança na compreensão de familiares. Rev. esc. enferm. USP 2011; 45(2):480-486.

16. Cardoso AL, Marcon SS, Waidmani MAP. Impacto da descoberta da sorologia positiva do portador de hiv/aids e sua família. Rev. enferm. UERJ 2008; 16(3):326-332.

17. Padoin SMM, Machiesqui SR, Paula CC, Tronco CS, Marchi MC. Cotidiano terapêutico de adultos portadores da síndrome de imunodeficiência adquirida. Rev. enferm. UERJ 2010; 18(3):389-393.

18. Silveira EAA, Carvalho AMP. Familiares de clientes acometidos pelo HIV/AIDS e o atendimento prestado em uma unidade ambulatorial. Rev Lat Am Enfermagem. 2002; 10(6):813-818.

19. Freitas HMB, Backes DS, Pereira ADA, Ferreira CLL, Souza MHT, Marchiori MRCT, Erdmann AL. Compreendendo o ser familiar de criança com Vírus da Imunodeficiência Humana/ síndrome da imunodeficiência adquirida pelo olhar da complexidade. Acta paul. enferm. 2010; 23(5):597-602.

20. Vieira M, Padilha MICS. O cotidiano das famílias que convivem com o HIV: um relato de experiência. Esc. Anna Nery 2007; 11(2):351-357.

21. Andrade HAS, Silva SK, Santos MIPO. AIDS em idosos: vivências dos doentes. Esc. Anna Nery 2010; 14(4):712-719.

22. Scherer LM, Borenstein MS, Padilha MI. Gestantes/ puérperas com hiv/aids: conhecendo os déficits e os fatores que contribuem no engajamento para o autocuidado. Esc. Anna Nery 2009; 13(2):359-365.

23. Schaurich D, Padoin SMM. Ser mulher cuidadora de criança com AIDS: compreensões existenciais à luz da filosofia de Buber. Texto Contexto Enferm 2008; 17(3):567-577.

24. Seidl EMFR, Rossi WS, Viana KF, Meneses AKF, Meireles E. Crianças e adolescentes vivendo com HIV/AIDS e suas famílias: aspectos psicossociais e enfrentamento. Psic.: Teor. e Pesq. 2005; 21(3):279-288.

25. Seidl EMF, Troccoli, BT. Desenvolvimento de escala para avaliação do suporte social em HIV/aids. Psic.: Teor. e Pesq. 2006; 22(3):317-326.
26. Goncalves TR, Piccinini CA. Experiência da maternidade no contexto do HIV/AIDS aos três meses de vida do bebê. Psic.: Teor. e Pesq. 2008; 24(4):459-470.

27. Remor EA. Aspectos psicossociais na era dos novos tratamentos da AIDS. Psic.: Teor. e Pesq. 2002; 18(3):283-287.

28. Seidl EMF, Zannon CMLC, Troccoli BT. Pessoas vivendo com HIV/AIDS: enfrentamento, suporte social e qualidade de vida. Psicol. Reflex. Crit. 2005: 18(2):188-195.

29. Guerra CPP, Seidl EMF. Adesão em HIV/AIDS: estudo com adolescentes e seus cuidadores primários. Psicol. estud. 2010; 15(4):781-789.

30. Codeço CT, Coelho CF. Redes: um olhar sistêmico para a epidemiologia de doenças transmissíveis. Cien Saude Colet 2008; 13(6):1767-1774.

31. Carvalho FT, Morais NA, Koller SH, Piccinini CA. Fatores de proteção relacionados à promoção de resiliência em pessoas que vivem com HIV/AIDS. Cad Saude Publica 2007; 23(9):2023-2033.

32. Carvalho CV, Duarte DB, Hamann EM, Bicudo E, Laguardia J. Determinantes da aderência à terapia anti-retroviral combinada em Brasília, Distrito Federal, Brasil, 1999-2000. Cad Saude Publica 2003; 19(2):593-604.

33. Marques HHS, Silva NG, Gutierrez PL, Lacerda R, Ayres JRCM, DellaNegra M, França Júnior I, Galano E, Paiva V, Segurado AAC, Silva MH. A revelação do diagnóstico na perspectiva dos adolescentes vivendo com HIV/AIDS e seus pais e cuidadores. Cad Saude Publica 2006; 22(3):619-629.

34. Paiva V. Sem mágicas soluções: a prevenção e o cuidado em HIV/ AIDS e o processo de emancipação psicossocial. Interface Botucatu 2002; 6(11):25-38

35. Forsait S, Castellanos MEP, Cordenonssi JT, Vicentini LL, Silva MMB, Miranda MC, Magalhães NP, Cartum J. Impacto do diagnóstico e do tratamento de câncer e de AIDS no cotidiano e nas redes sociais de crianças e adolescentes. Arq Bras Ciên Saúde 2009; 34(1):6-14.

36. Vasconcellos D, Picard O, Ichaï SC. Condições psicológicas para a observação das terapias antiretrovirais altamente ativas (HAART). Rev. psiquiatr. 2003; 25(2):335-344.

37. Carvalho CV, Merchán-Hamann E, Matsushita R. Determinantes da adesão ao tratamento anti-retroviral em Brasília, DF: um estudo de caso-controle. Rev. Soc. Bras. Med. Trop. 2007; 40(5):555-565.

38. Pupulin ART, Bertolini DA, Lonardoni MW, Shimauti E, Spack Junior M, Motta DD, Araujo SM. Influência do apoio psicossocial para pacientes com infecção pelo vírus HIV. Rev panam infectol 2007; 9(1):9-14.

39. Sousa AS, Kantorski LP, Bielemann VLM. A aids no interior da família - percepção, silêncio e segredo na convivência social. Acta sci. Health sci 2004; 26(1):1-9.

40. Tavares JSC. Redes sociais e saúde: explorando o universo de famílias de classe popular e seu entorno comunitário [tese]. Salvador: Universidade Federal da Bahia; 2009.

41. Brasil. Ministério da Saúde (MS). Diretrizes para o fortalecimento das ações de adesão ao tratamento para pessoas que vivem com HIV e AIDS. Brasília: MS; 2007. [acessado 2013 ago 28]. Disponível em: http://bvsms. saude.gov.br/bvs/publicacoes/diretrizes_tratamento aids.pdf

Article submitted 06/05/2014

Approved 10/05/2014

Final version submitted 12/26/2014 